\title{
LUHMANNŬV TEORETICKÝ POKUS O POSTIŽENÍ KOMPLEXITY MODERNÍ SPOLEČNOSTI
}

\author{
JIŘi ŠUBRT
}

\section{Niklas Luhmann - teoretik moderní společnosti}

Německý sociolog Niklas Luhmann (nar. 1927) patři mezi ty badatele, kteří usilují o vymanění sociologie z jejích tradičních, vyjetých kolejí a snaží se dát jí nový směr a orientaci. Díky svému rozsáhlému originálnímu dílu se stal světově uznávaným teoretikem, jehož knihy se překládají do řady světových jazyků. Základním tématem Luhmannových studí je moderní společnost; jeho cílem pak je přispět k porozumění tomuto typu společnosti, a to především cestou teoretického postižení složitosti (komplexity) jejích vżahi̊.

Luhmann je tvi̊rcem a reprezentantem systémové teorie (systémového paradigmatu). Podle Helmuta Willkeho to byla právě tato teorie, která formovala teoretický diskurz a rozvíjení teorie v sociologii během osmdesátých let (Willke 1991: V). Žádná jiná orientace nebyla s to rozvijet se s takovou dynamikou. Systémová teorie poskytuje podle Willkeho univerzálnost odborně specifickou i univerzálnost interdisciplinární (spojuje sociologii s ostatními vědami).

Luhmannova teorie, vycházející z paradigmatu autopoietických systémů a umožňující popsat vazby a chování vysoce strukturovaných, nezávislých a diferencovaných oblastí moderního sociálního života, nepatří $\mathrm{k}$ snadno prístupným a osvojitelným teoriím. Luhmann sám přirovnává svoji teorii spíše $\mathrm{k}$ labyrintu než $\mathrm{k}$ silnici vedoucí k št’astnému cíli (Luhmann 1993: 14). A najde se pochopitelně i nemálo těch, kteňi (jako např. Walter Bühl) kritizují Luhmanna za spekulativnost a fantastičnost jeho teoretických konstrukcí (Bühl 1987).

Právnické studium (1946 - 1949) ve Freiburgu a studijní pobyt v USA na Harvardu (1960-61) u Talcotta Parsonse podstatně ovlivnily rozvoj Luhmannova teoretického myšlení. V sedmdesátých a osmdesátých letech se zapsal do povědomí odborné veřejnosti v SRN mj. i svými úspěšně vedenými polemikami s Jürgenem Habermasem. Většina Luhmannových děl, k nimž patři např. Soziale Systeme (1984) nebo Die Wirtschaft der Gesellschaft (1989) vychází v jednom z nejvýznamnějších německých nakladatelství, v Suhrkamp-Verlag. Další německé nakladatelství Westdeutscher Verlag vydává od r. 1970 svazky Luhmannových sebraných statí, které jsou uspořádány pod názvem Soziologische Aufklörung (vyšlo již pět svazkii). 
Aufklärung - pojem, který má v německém sociologickém myšlení svoji určitou tradici - chápe Luhmann antitradicionalisticky, jako kritickou analýzu společnosti, kritiku sociologického vědění a metody. Součástí tohoto postoje je u Luhmanna odklon od historické linie sociologického myšlení, jejíž vliv na soudobou sociologii považuje za fatální a svazující (Luhmann 1991a: 66 an.).

Luhmann je kritikem současného stavu teoretické sociologie; vytýká jí tradiční orientaci, zastaralé pojmosloví, neschopnost patřičně objasnit a vysvětlit procesy, které se odehrávají v moderní společnosti. Veden nedůvěrou $\mathrm{k}$ sociologii tradičního typu odmítá přeceňování kontinuity sociologického tázání a návratů ke „klasikům“ oboru. Opouští př́stupy autorů, jakými byli Weber, Durkheim či Pareto, a namísto toho předkládá svi̊j vlastní model sociologické teorie.

Soudobá sociologie, svazovaná svou tradicí, nedrží podle Luhmanna krok s vývojem vědeckého myšlení. Proto jej spiše než pohled do dějin oboru zajímají podněty, které vycházejí z jiných oblastí; interdisciplinární charakter sociologie má pritom zabránit jejímu př́lišnému zahledění do sebe sama.

V Luhmannově sociologickém myšlení se odráži řada vlivů, včetně termodynamiky, kybernetiky, informační teorie, biologie a neurofyziologie. Vedoucí disciplínou pro něj není v současné době fyzika či astrofyzika, nýbrž biologie genetického kódu a kognitivní biologie. Sám je ovlivněn z velké míry operativní logikou Georga Spencera Browna a biologickou teorií poznání chilského neurofyziologa Humberta R. Maturany.

Luhmann klade velký důraz na adekvátnost odborného jazyka. Kritizuje inflaci sociologického žargonu a snaži se vyvinout vlastní teoretickou řeč (což je jedním z di̊vodů, proč je mnohdy obtížné i pro jeho německé čtenáře mu správně porozumět), která by odpovídala té úrovni, již dosáhly jiné vědy ( $\mathrm{z}$ tohoto hlediska považuje Luhmann za „št'astná" století, v nichž věda používala svůj vlastní jazyk - latinu - odlišný od jazyka použivaného v běžné mezilidské komunikaci) (Luhmann 1990: 388). Pojmosloví Luhmannovy sociologie se zprvu vyvíjelo pod vlivem Parsonsovy teorie, brzy však překročilo její hranice a začalo čerpat podněty $z$ ostatních věd, zejména kybernetiky a biologie.

Luhmannovy výtky se ovšem nevztahuji pouze $\mathrm{k}$ pojmosloví, ale především $\mathrm{k}$ modelům, které zastupují v sociologické teorii sociální realitu; proto podniká určitý pokus o aplikaci nového, systémového paradigmatu.

Zpočátku se Luhmann neubránil Parsonsovu vlivu. Byl mu sympatický jeho pokus založit univerzálně platnou, všeobecnou sociologickou teorii („teorii pro všechny př́pady“) na nové, systémové bázi. Luhmanni̊v způsob myšlení měl, zejména v počátcích, mnoho shodných rysů s Parsonsovým (proto byl také některými kritiky ironicky označován za jeho „pohrobka“) (Mucha 1989:163). Z tohoto vlivu se však postupně vymanil. Luhmannův vztah $\mathrm{k}$ Parsonsovi je celkově možné vyjádřit německým: „Zwar-aber".

V Parsonsově koncepci se jako zásadní jeví otázka struktur. Systém je určen interdependencí svých částí, vztah částí a celku je klíčový. Společnost se rozpadá na dílčí systémy; celkovému systému společnosti jsou podřazeny jednotlivé dílčí subsystémy (sociální systém, kulturní systém, organismy, osobnosti) (Parsons 1976: 275 an.). Zá- 
kladní problém - udržení systému - se Parsonsovi jeví jako problém symbolické generalizace hodnot, které přes svou internalizaci jednajícími subjekty zajištujuí integraci sociálního systému.

Pro Luhmanna naproti tomu jsou systémy něčím více než jen částmi a celkem; nelze je redukovat na relace mezi různými elementy; mnohem důležitější (než pro Parsonse) je pro něj otázka hranic systému a stabilizace diference mezi vnitřním a vnějším. V protikladu $\mathrm{k}$ Parsonsovi ho také nezajímá společenský hodnotový systém, a proto ani pojem „kulturní systém“ nehraje u Luhmanna žádnou roli.

Klíčovou otázkou je pro Luhmanna způsob fungování systému, nikoliv jeho struktury. Jestliže $\mathrm{v}$ tradičním funkcionalismu slouží funkce $\mathrm{k}$ zajištění stavu konkrétního sociálního systému, Luhmann naproti tomu předřazuje pojem funkce na první místo, před pojem struktura. Je-li Parsons strukturním funkcionalistou, pak Luhmann je především funkcionalistou (Treibel 1993: 25), jeho teorie je konsekventně funkcionální analýzou.

Už od dob Thomase Hobbese sociální vědci nastolují otázku, jak je vưbec sociální rád možný? Luhmann vyvodil ze své funkcionální analýzy metodologický recept: Hledat teorii, kterou se podaří vysvětlit normální jako nepravděpodobné (Luhmann 1993: 162), nebo jinými slovy: Vysvětlit, jak se nepravděpodobné stává normálním. Luhmann zpracovává problematiku společenského systému ve třech rovinách, v rovině teorie systému, evoluční teorie a komunikační teorie (někdy se uvádí ještě čtvrtá oblast, teorie smyslu a sebereference). Tyto roviny se vzájemně prolínají a překrývají.

Předběžně lze konstatovat, že $\mathrm{v}$ rovině teorie systému je společnost vykládána jako systém, který se diferencuje vzhledem ke svému prostředí a který se skládá z určitých elementů a relací (interakcí) mezi nimi. Evoluční teorie zkoumá procesy umožňující společenský vývoj; procesy variace, selekce a stabilizace. V rovině teorie komunikace je pak analyzována tvorba společenských systémů. Společnost je tedy interpretována jako sociální systém založený na komunikaci, který se evolučně vyvijí (jde o „evolující"systém).

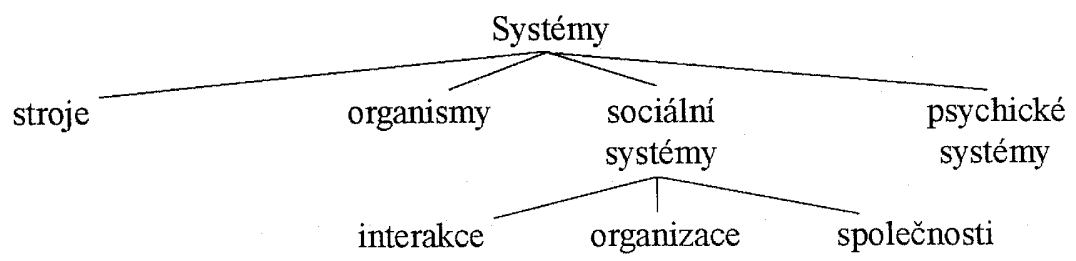

(Luhmann 1993:260)

V rámci sociálních systémů Luhmann odlišuje interakční systémy, organizační systémy a společenské systémy (Luhmann 1991b: 10 an.). Jedná se o tři úrovně tvorby systémů: Interakční systémy jsou diferencovány prítomností (např. účast studenti̊ na přednášce), organizační systémy jsou definovány pravidly členství (např. vysoká 
škola), společenské systémy jsou systémy všech komunikativně vzájemně dosažitelných jednání (např. Spolková republika). Luhmann se ve svém díle zabývá především těmi nejobsáhlejšími sociálními systémy, tedy společnostmi, podmínkami jejich vzniku a jejich vysoce komplexní výstavbou.

Otázka vzniku sociálnúho řádu je pro Luhmanna otázkou tvorby sociálního systému. Sociální systémy se utvářejí procesy autokatalýzy (Luhmann 1993: 260). Dủležitou roli v procesech tvorby a udržování systémů hraje selekce v rámci možného, tedy redukce komplexity. Tvorba sociálních systémů je určitým pokusem uvést v soulad množství možností, které jsou na „světě“; je spojena jednak s vymezením vnitřní a vnější dimenze sociálnílho systému (zde Luhmann navazuje na již vytvořené kybernetické varianty teorie systému, které chápou pomèr systému a okolí jako diferenci $\mathrm{v}$ komplexitě), jednak $\mathrm{s}$ vývojem vnitřní komplexity systému, která je v určité relaci ke komplexitě vnější.

Ve strukturním funkcionalismu představovala sociální změna cosi obtížně vysvětlitelného. Luhmannovo pojetí systémové teorie tento problém překonává. Luhmann podobně jako např. Anthony Giddens zamítá představu sociální struktury jako něčeho statického, a naopak zdi̊razn̆uje, že sociální systémy jsou proměnlivé, že jsou produkovány a reprodukovány $\mathrm{v}$ čase a s časem.

Další standardní výtkou proti strukturněfunkcionalistickému způsobu myšlení v sociologii je bezdějinnost. V Luhmannově sociologii hraje naproti tomu tato historická dimenze mimořádně dúležitou roli. Luhmann na rozdíl od Giddense je ovšem zastáncem evoluční teorie; ta má být $v$ jeho pojetí teorií historických souvislostí růstu a změn struktury sociálního systému.

V dřivějších koncepcích evoluční teorie převládal názor, že evoluce je zákonitým procesem změn, který byl často spojován s představou o civilizačním růstu, sociálním pokroku, narůstající humanitě atd. Tato vidina je v moderní variantě evoluční teorie opuštěna. Oproti minulým pojetím není evoluce chápána jako zákonitý proces změn, není spojována s determinací ani s kumulací náhod, nelze ji redukovat ani na di̊sledek boje, adaptace či přizpůsobení, a není také vysvětlována kauzálně jako průběh, ve kterém je předešlý stav prríčinou stavů následujícich.

Luhmann soudí, že evoluce je z hlediska své orientace do budoucnosti slepá. Moderní evoluční teorie se zaměřje pouze na popis reálných změn. Pro Luhmanna je evoluce specifickou, strukturální, permanentně se měnící kvalitou systémů („specifickým mechanismem strukturálních změn“, „specifickou formou změny struktury") (Kiss 1986: 41). Změny, k nimž v systémech dochází, objasňuje Luhmann především prostřednictvím pojmů variace, selekce a stabilizace.

Evoluční teorii Luhmann aplikuje na výklad strukturálních změn společností přitomných i minulých. V této souvislosti hovoř́ o vývoji, který vede od od tzv. segmentární přes stratifikovanou až $\mathrm{k}$ moderní funkcionální společnosti. Pro archaické společnosti byla typická segmentární diferenciace, následující typ společností byl diferencován stratifikačně, moderní společnost není charakterizována hierarchiemi (tř́idami nebo vrstvami), nýbrž funkcemi; je podstatně diferencována funkcionálně (i když stratifikace stále ještě existuje, ztrácí na svém významu) (Treibel 1993: 24). 
V průběhu evoluce narůstá komplexita společností. Stupeň funkcionální diferenciace společnosti je pro Luhmanna specifickým znakem společenského vývoje. Moderní společnost je ve srovnání se staršími společenskými formacemi funkcionálně diferencovanějším systémem (tamtéž). V průběhu evolučního procesu se postupně vyčlenily takové funkcionální oblasti jako hospodářství, politika, vzdělání, právo, věda či náboženství. Tyto oblasti se $\mathrm{v}$ moderní společnosti přetvořily do podoby autonomních, uzavřených, sebereferenčních systémů, jejichž vzájemná jednota je formována vztahy založenými na kombinaci funkcionální uzavřenosti systémů a jejich otevřenosti vůči prostředí.

Vedle narůstající komplexity je jedním z rysů moderní společnosti absence záruky její vlastní integrace, kterou dřive zaručovala dominance jednoho $z$ uvedených systémů společnosti nad ostatními. Tím se moderní společnost stává labilnější a zranitelnější.

\section{Komplexita}

Luhmannova teorie si klade za cíl popsat svět za pomoci rozlišení pojmů systém a prostř̌edí. Systém, jak již bylo řečeno, je charakterizován jednak svými hranicemi vǔči prostředí, jednak určitými vnitřními relacemi (vztahy). I když by se mohlo zdát, že pojem systém poukazuje na jednotu, je nutno konstatovat, že Luhmann není teoretikem jednoty, nýbrž teoretikem diference (Reese-Schäfer 1992: 10). Operuje zásadně s pojmovými opozicemi; za základní považuje nikoli relaci systém - podsystém, nýbrž dichotomii systém - prostředí (tzn. diference a jistý stupeň napětí mezi nimi) (Luhmann 1993: 242 an.). Na začátku tedy nestojí identita, ale diference, to je jádro Luhmannova uvažování.

Luhmann doprovázi své náročné výklady řadou jednoduchých př́kladů, které nemají být chápány jako důkazy potvrzující jeho teoretické vývody, nýbrž mají čtenáři věci prriblížit, pobavit ho a usnadnit mu čtení. Máme-li v tomto smyslu přibližit problematiku systému a prostředí, můžeme konstatovat, že např. pračka je systém technických zařízení, jako je hadice, buben nebo pumpa, které jsou navzájem v určitých vztazích. Hranice takového systému jsou jednoznačně stanoveny, takže je jasné, co je pračka a co pračka není, co je např, zed' nebo okno.

To, co se nalézá vně systému, je prostředí. Prostředí chápe Luhmann jako to, co není systém (Nichtsystem). Např. vytváření systému rodiny je založeno na stanovení hranic toho, co je rodina a co rodina není, co je mimorodinné prostředí. Prostředí poskytuje vždy více možností, než si systém může přisvojit a zpracovat, je tedy nutně komplexnější než systém sám; ve srovnání s prostředím jsou systémy méně komplexní. Prostředí v Luhmannově pojetí není pouze množství systémů obklopujících jeden určitý systém a penetrujících do něj, nýbrž také ještě netematizované, potenciální oblasti a možné světy pro další vývoj.

Vztah mezi systémem a prostředím spojuje Luhmann s pojmem rezonance (Reese-Schäfer 1992: 128). Systémy v tomto smyslu nejsou dirigovány faktory okolního světa, nýbrž je „rezonuji“‘; tato rezonance závisí na interních strukturách a vnitřních stavech systému. 
Sociální systémy mohou existovat jen díky tomu, že redukují komplexitu světa. Komplexita a kontingence představují dva pojmy, které jsou v Luhmannově koncepci klíčové.

Komplexita znamená mnohost a mnohoznačnost, resp. to, že je vždy více možností, než je realizováno. (Kiss 1986: 7 an.) Tvorba systému je chápána jako selekce z množství a možností, tedy jako redukce komplexity. Všechno, co bylo o systémech řečeno (tzn. otázka jeho částí, tvorby hierarchií, stanovení hranic, diferenciace struktur, procesů atd.) - lze analyzovat jako redukci komplexity.

Proto se v Luhmannových textech setkáváme s tím, že pojmem komplexita již není označována ona pưvodní potenciální mnohost, nýbrž právě komplexita redukovaná: V systémech, kde je více prvků, není možné, aby každý z nich byl postaven do vztahů se všemi ostatními. Možná spojení mezi prvky je nutné omezit. Proto jsou stanoveny selekce vztahů nebo vzory těchto selekci, čímž jsou předběžně vyloučeny určité relace, které samy o sobě by možné byly. Jako komplexní označuje Luhmann ty souvislosti, kde není každý element spojen s každým (Luhmann 1993: 46).

H. Wilke ve svém učebnicovém výkladu systémové teorie rozlišuje věcnou, sociální, časovou, operativní a kognitivní komplexitu systému.

Se vzri̊stající komplexitou sociálních systémů vzniká problém - praktický i teoretický - jak uvedenou mnohost zmenšit. Protože ,jen komplexita může redukovat komplexitu“" (1984:49), nejen společnost, ale i teorie musí být stále komplexnější. Podle Luhmannových vlastních slov by se systémová teorie měla stát „superteorii“", kterou lze přirovnat k benzinu „se zvýšeným oktanovým číslem“ (Reese-Schäfer 1992: 101).

Pojmem komplexita postihuje Luhmann to, co jiní teoretikové vyjadřují pojmy moderna a modernizace. V průběhu společenské evoluce dochází $\mathrm{k}$ vzrůstání komplexity sociálních systémů. Komplexita souvisí s druhým znakem moderní společnosti, s její rostoucí funkcionální diferenciací (ve funkcionální diferenciaci moderní společnosti vidí Luhmann hlavní rozdíl oproti dřivějším společenským formám). Rostoucí komplexita a funkcionální diferenciace jsou hlavní znaky moderní společnosti, které spolu vzájemně souvisejí; bez diferenciace by nebyla komplexita.

Společnost se stává diferencovanější tím, že se jednotlivé oblasti sociálního života postupně vydělují ze svého prostředí. Různé subsystémy společnosti jako hospodářství, politika, věda nebo právo se osamostatňují a stále více specializují (např. právo se diferencuje na různé oblasti, jako je právo soukromé, veřejné, trestní, občanské, hmotné, procesní).

Funkce a struktury moderní společnosti zasahují najednou mnoho rovin, přičemž ne všechny elementy systému mohou spolu být navzájem spojeny. Jak jsme již konstatovali, rostoucí komplexita sociálního systému je spojena s tendencí tuto komplexitu redukovat; je-li komplexita základním znakem moderní společnosti, pak hlavním úkolem je její redukce. Jde o redukci, která je založena na selekci a výběru možností. Společnost i každý její jednotlivý systém si stanovují určité selektivní mechanismy, které vedou $\mathrm{k}$ vnitřní strukturaci těchto systémů. Čím je systém komplexnější, tím větši možnost voleb v sobě zahrnuje a tím se ovšem také zvětšuje potenciál možných rizik. Zde se Luhmann dotýká otázky ohrožení moderny; díky své funkcionální diferen- 
covanosti jsou moderní společnosti nejen výkonově schopnější, ale také náchylnější k poruchám a konfliktům.

\section{Autopoiesis - nové paradigma systémové teorie}

Jestliže Luhmann v jedné ze svých charakteristických formulací lapidárně konstatuje: „Es gibt Systeme“" (Luhmann 1993: 31), znamená to, že systémy pro něj nejsou jenom nějakou myšlenkovou konstrukcí nebo vědeckým modelem, nýbrž že reálně existují.

Vývoj teoretického uvažování o systémech lze rozčlenit na tři etapy (Morel 1995: 190). První etapa sahá až na počátek novověku a je spojena s paradigmatem „části a celku" (v sociologii se toto paradigma projevilo např. v díle E. Durkheima). Druhé velké paradigma podržuje koncept „části a celku“, ale klíčové je pro ně odlišení „systému a prostředí" (to je paradigma, které rozpracovává Parsons a v počátcích svého bádání se $\mathrm{k}$ němu připojil také Luhmann). Od konce sedmdesátých let je možné $\mathrm{v}$ Luhmannově díle zaznamenat názorový posun, který nese znaky třetího paradigmatu: Diferenciace „systém - prostředi“ zůstává zachována jako základní, ale je stále méně důležitá. Pod vlivem nových poznatki̊, ke kterým dospěla zejména kognitivní biologie, jsou sociální systémy charakterizovány jako „autopoietické systémy“.

Změna paradigmatu se v Luhmannově myšlení ovšem ohlašovala již dřive. Na rozdíl od Parsonsovy koncepce systémů, které jsou otevřeny (ve formě Input/Output). svému prostředí, Luhmann zdůrazñuje uzavřenost a sebereferenci sociálních systémů; přesouvá těžiště svých úvah od otevřených $\mathrm{k}$ uzavřeným systémům.

$\mathrm{U}$ uzavřených systémů je nutné vycházet $\mathrm{z}$ jejich neredukovatelné autonomie a schopnosti stanovit si své vlastní mechanismy stabilizace, fungování a vývoje. Tyto systémy jsou založeny na sebereferenci (samy sebe organizuji). Sebereferenčně uzavřené systémy se $\mathrm{v}$ tomto pojetí vưči sobě navzájem chovají jako nezávislé „černé skřínky“", které sice mají možnost vzájemné interpretace, ale tato interpretace má vždy kontingentní povahu (P̌̌ibáň 1996: 135).

I když jsou systémy ve své výstavbě a reprodukci systémy uzavřenými, neznamená to, že nevytvář́jí kontakt s prostředím; naopak, bez těchto kontaktů by i dynamika uzavřených systémů zanikla. Např. univerzita jako systém může existovat pouze na pozadí fungujícího hospodárství, politického systému, právního systému atd.

Změna paradigmatu si vyžádala redefinování sociálního systému. Podle pưvodních Luhmannových představ - v duchu tradice (Weber, Parsons) - bylo za konstitutivní prvek sociálních systémů považováno jednání. Sociální systémy v tomto pojetí předpokládají, že je na sebe navzájem smysluplně vztaženo jednání více osob, a tím je zároveň oddělené a ohraničené od prostředí, které k němu nenáleži (Luhmann 1991b: 9).

Nově jsou pak sociální systémy definovány jako autopoietická souvztažnost konstituovaná komunikací. I v tomto př́padě je evidentní ohraničenost systému vzhledem $\mathrm{k}$ jeho prostředí; zdůrazněno však je, že sociální systémy se skládají nikoli z lidí a jejich jednání, nýbrž z komunikací (Luhmann 1986: 269). Ne tedy už jednání, nýbrž komunikace je tím, co vytvárí systémy. 
Pojem autopoietický systém - odvozený od umělého výrazu autopoiesis (tedy z řeckého autos = sám, poien = tvořit, dělat) - vyjadřuje jednoduše řečeno to, že systém má schopnost sám sebe vytvářet, anebo - o něco přesněji - že jednotlivé systémy se vyvíjejí autonomně, a to tak, že realizují možnosti, které jsou obsaženy v síti prvků (elementů), z nichž jsou složeny (Mucha 1989: 154).

Výraz autopoiesis Luhmann převzal z biologie, od Humberta R. Maturany a Francesca J. Varely. Maturana chápe biologický systém jako sít' produkce svých vlastních součástí. Živé systémy, jako např. tělesné buňky, patř́ k autopoietickým systémům, nebot' se vyznačují silnou vlastní vnitřní dynamikou (na rozdíl od živých systémů nejsou např. stroje žádným autopoietickým systémem, i když podobně jako buňky mají input z prostředí a output, protože jsou orientovány nikoliv na výstavbu a zachování svých vlastních struktur, nýbrž na zhotovování produktii).

Luhmannovo hlavní dílo Soziale Systeme s podtitulem Grundriß einer allgemeinen Theorie je pokusem učinit z výrazu autopoiesis jeden ze základních sociologických pojmů. V biologickém pojetí znamená autopoiesis sebetvorbu/sebereprodukci života, v sociologickém pojetí se jedná o sebetvorbu/sebereprodukci sociální reality. Pojmem autopoiesis je mj. vyjadřeno to, že systémy jsou operativně uzavřené a samy sebe organizuji (ještě předtím, než začal Luhmann používat pojem autopoiesis, objevuje se $\mathrm{v}$ jeho pracích pojem sebereference, ale také sebeorganizace, sebevztaženost - Selbstbezüglichkeit nebo sebetematizace; do značné míry je proto oprávněné považovat tato slova za synonyma).

Autopoietické systémy se ve své základní cirkularitě reprodukují tím, že systém reprodukuje prvky, z nichž sestává, s pomocí prvků, z nichž se skládá (Willke 1991: 43). Z aktivit elementů systému vznikají struktury, jejichž trvání není časově neomezené, naopak jsou v neustálém pohybu a proměnách, přičemž zejména v moderních společnostech je tento proces zvláště dynamický.

$S$ pojmem autopoiesis úzce souvisí pojem autonomie a emergence. Autonomie systému je nejobecnější formou sebereferenční uzavřenosti a autopoiesis jejím speciálním případem, který je dán jen tehdy, když se prvky systémů reprodukují z proki̊ systému v nejpř́snějším smyslu. Pojem emergence označuje ony vlastnosti systému, které nejsou vysvětlitelné z vlastností svých prvků; jsou tedy nové a charakteristické jen a teprve pro rovinu daného systému. Tyto vlastnosti nelze přičítat prvkưm samým, nýbrž jejich určitým selektivním spojením v kontextu daného systému (tamtéž: 100).

\section{Komunikace, smysl a kontingence}

Systémová teorie ve svých různých variantách se již tradičně pokouší řešit otázky, z jakých jednotek (elementů) se sociální systémy skládají, jak jsou tyto jednotky konstituovány a jak se organizuji do struktur. Luhmann na tyto otázky odpovídá tak, že definuje sociální systémy jako systémy smysluplné komunikace. Sociální systémy vznikají mezilidskou komunikací. Tím elementárním, co konstituuje sociální realitu, je komunikační proces (Luhmann 1993: 193). Základními jednotkami sociálních systémů nejsou pro Luhmanna individua, individuální aktéři, nýbrž komunikace. 
Ty představují jakési emergentní jednotky, které uvádějí do chodu mechanismy selekcí a výběru možností vedoucí $\mathrm{k}$ výstavbě struktur, jež potom fungují jako podmínka možnosti další komunikace.

Luhmann vzdálil pojem komunikace běžnému pojetí, v jakém je uživán v každodenní řeči. Zajímá se o komunikaci jako takovou, ne o komunikující lidi. Komunikace je v Luhmannově podání relativně uzavřeným, abstrahovaným systémem, syntézou určitých selektivních pochodů. Vzniká, dojde-li k syntéze tří selekcí: (tamtéž: 203). 1. informace (někdo něco vybírá $z$ množství), 2. sdělení (je třeba vybrat i způsob, jak to sdělit), 3. pochopení, porozumění (event. 4. selekce - prijetí, odmítnutí komunikace).

Uvědomíme-li si, jaké možnosti odmítnutí se tu v jednotlivých krocích nabízejí, stává se nám zřejmou ona nejistota a nestabilita, které jsou vlastní všem komunikačním a interakčním procesưm; komunikace se jeví jako značně nepravděpodobná (nepravděpodobné je, že informace dostihne adresáta, že jí bude rozumět, že ji príjme a že odpoví).

Imanentní nepravděpodobnost je podle Luhmanna charakteristickým rysem komulnikačního procesu. Způsob, jak tuto nepravděpodobnost překonat a transformovat na pravděpodobnost, ř́dí výstavbu sociálních systémů. Proces sociokulturní evoluce se $\mathrm{z}$ tohoto pohledu jeví jako transformace a rozšíření šancí pro slibnou komunikaci. Není to jednoduše proces ri̊stu, nýbrž selektivní proces, který určuje, jaké druhy sociálních systémů jsou možné a co bude vyloučeno.

Evoluční vymoženosti, které transformují nepravděpodobnost komunikace na pravděpodobnost, nazývá Luhmann médii (tamtéž: 220). Zde navazuje na Parsonse a rozvíjí jeho koncepci „výměnných“, „symbolických“ médií.

Takovými komunikačními médii jsou pro Luhmanna např. pravda, láska, moc, penize, částečně umění, náboženská víra nebo její sekularizovaná forma „základní hodnoty". Komunikace v tomto pojetí představuje přenos smyslu prostřednictvím specifických prostředki̊, médií a kódi̊.

Sociální systémy vykazují vysokou míru uspořádanosti (negentropie). Jednotlivé elementy nenavazují na jiné libovolně, nýbrž jejich relace jsou omezeny selekcemi, které určují strukturu systému. Pokud jde o komunikaci, omezení je předem dáno tématy. Témata jsou v tomto smyslu redukcemi; celkový soubor tematických zásob představuje kulturu. Č́sti pokládané za cenné pro zachování kultury označuje Luhmann jako sémantiky. Jako př́klad může posloužit sémantika lásky - předpisy, jakým způsobem lze $\mathrm{v}$ intimním jednání a proživání věci vyjádřit, očekávat, vyžadovat, potlačit nebo odmítnout (Luhmann 1982).

Pro Luhmannův způsob sociologického myšlení je charakteristické vyloučení problematiky subjektu a intersubjektivity. $Z$ tohoto důvodu Luhmann kritizuje jak pokus Richarda Müncha vykládat teorii systému $v$ intencích Weberovy teorie jednání, tak i snahu Jürgena Habermase zkoumat komunikaci a jednání z perspektivy teorie komunikativního jednání.

Odmítnutí subjektu se u Luhmanna pojí s představou, že svět není to, co mohu popsat z jednoho bodu (Reese-Schäfer 1992: 106). Luhmann ponechává pojem subjektu filozofické tradici; sám použivá pojmy jako člověk, individuum, osoba: Osobnosti nebo individua jsou označovány jako psychické systémy nebo personální systémy; ty ovšem Luhmann nezkoumá, předmětem jeho zájmu jsou systémy sociální. 
Někteři kritikové soudí, že Luhmannova teorie je nehumánní, protože projektuje společnost bez lidí. Jedná se ovšem o metodologický antihumanismus, nikoliv o normativ. Tento metodologický antihumanismus je založen na premise, že konkrétní lidé, jejich organické a psychické vlastnosti patří $\mathrm{k}$ prostředí sociálního systému. Tím ovšem není a nemá být řečeno, že lidé jsou pro sociální systémy nedůležití. Např. psychické systémy Charloty W. nebo Rudiho $\mathrm{H}$. nejsou jako takové částmi sociálního systému „přednáška“, nýbrž pouze jeho funkcionálními součástmi jako studenti a studentky. Lidé - přibližně pět miliard psychických a organických systémů - jsou počítáni k prostředí (tamtéž: 110). Sociální systémy (jako rodina, instituce, vláda atd.) musejí být zkoumány odděleně od personálních systémů - individuí.

Uved'me v této souvislosti ještě jeden „luhmanovskýc př́klad: Když např. žena kupuje u řezníka uzenku, patř́ elementy tohoto jednání do sociálního systému rodiny, kterou zásobuje, a do systému obchodu, $\mathrm{v}$ širším rámci do hospodářského systému. Styl jejího př́chodu, míra její kritičnosti vůči zboží, výběr slov a chování, to vše je nutno přičíst její individuální osobnosti.

Na první pohled se zdá být toto stanovisko jasné, skrývá však v sobě určitý metodologický problém, $\mathrm{k}$ jehož přibližení stačí připomenout, že např. pro Pierra Bourdiena jsou druh a způsob chování nikoli výrazem individuality osobnosti, ale tzv. sociálního habitu, který představuje sociologickou kategorii.

Organické, psychické a sociální systémy se podle Luhmanna ve své výstavbě navzájem ovlivňují. Pro vztahy mezi člověkem a sociálním systémem používá Parsonsův pojem interpenetrace. Interpenetrace v Luhmannově pojetí předpokládá, že dva systémy se mohou vzájemně umožňovat tak, že si vzájemně dají k dispozici svoji předem konstituovanou komplexitu (Luhmann 1993: 290). Samy při tom nesplývají, ale zi̊stávají jeden pro druhého prostředím. Interpenetraci umožňuje, je, že jsou si sociální a psychické systémy „podobné“ v tom, že „použivají smysl“ (tím se liší např. od systémů - strojů).

Ne všechny systémy zpracovávají komplexitu a sebereferenci ve formě smyslu, psychické i sociální systémy ano. Sociální systémy jsou systémy smysluplné komunikace; smysl je nutným předpokladem pro komunikaci. Komunikace v tomto pojetí je něčím jako stálé „sebedrážděni“ a „sebezaplavováni“ smyslem v systému (Luhmann 1993: 236).

Smysl jako operativní modus sociálních systémů je pro Luhmanna jedním ze základních pojmů sociologie. Umožňuje nejen komunikaci a interpenetraci sociálních a psychických systémů, ale také selekci a redukci komplexity (přisuzováním smyslu je možné vylučovat možnosti, rozlišovat to, co $\mathrm{k}$ systému náleží a co $\mathrm{k}$ němu nenáleží). A konečně také - výběr podle hledisek smyslu je i důležitým evolučním kritériem.

$\mathrm{V}$ dějinách evropského myšlení je otázka smyslu chápána různým způsobem. $\mathrm{V}$ antické tradici a středověku je smysl chápán jako pojem reality, který má kosmologický charakter. V novověké tradici převzala funkci selekčního kritéria, které určuje a vylučuje to, co smysl nemá a co je nechtěné, teorie subjektu. Na tento směr navazuje i německá duchovědní tradice, která se odrazila v sociologii $\mathrm{M}$. Webera. Jiná tradice chápání smyslu je spojena s hermeneutikou; zde je pojem smyslu zaměřen na uspořádání rozrazených souvislostí, aby text byl srozumitelný ve svém kontextu. 
Žádné z těchto pojetí ovšem Luhmannovi nevyhovuje. Chápe smysl podstatně jinak než např. Max Weber nebo Alfred Schütz. Pro Webera je východiskem „subjektivně míněný smysl“", ale Luhmann, který v principu tento pojem přejímá, škrtá právě ono „subjektivně míněnýc jako omyl pramenící z novokantovského způsobu uvažování.

Schütz se pokusil tento nedostatek prekonat pomocí intersubjektivity, ale ani to pro Luhmanna nepředstavuje řešení.

V Luhmanově pojetí lze smysl předběžně charakterizovat jako selekci z okruhu možností. Smysl z hlediska jeho významu pro systém je čímsi jako pořádající formou světa (nikoli však ve starém kosmologickém pojetí jako rozum ztělesněný v kosmu). Luhmann chápe smysl jako evoluční pojem, resp. jako něco, co běži tak říkajíc samo od sebe. Smysl v tomto pojetí nepotřebuje žádného zvláštního nositele; nese sám sebe (Luhmann 1993: 141) tím, že umožňuje sebereferenčně svou vlastní reprodukci. Samohybnost smyslových událostí je autopoiesis par excellence.

Pokud bychom měli vuibec hovořit o nějakém nositeli smyslu, pak je jím diference v poukazování smyslu, která má svůj důvod v nutné selektivitě (tamtéž: 142). Tím, co iniciuje tento proces, je informace, která je diferencována jako událost vyvolaná stavy systému. Všechno, co ve světě systémů smyslu (Sinnsysteme) má být recipováno a zpracováno, musí mít formu smyslu.

V Luhmannových textech se nikde nesetkáme se stabilními věcmi, ale vždy jen s plynoucími strukturami smyslu. Smysl není ničím stabilní, ale je spíše jakýmsi potenciálem neklidu, který je založen na výběru právě aktuálního $\mathrm{z}$ horizontu možností. Smysl je procesuálním pojmem orientovaným na diference; sám sebe „procesuje“ podle míry diferencí, které jako takové nejsou predem dány.

V situaci přebytku možností je kladení smyslu tím, co člověku pomáhá strukturovat realitu. Nahlíženo optikou jednotlivce znamená smysl význam, který pozorovatel spo.juje s pozorovaným. Luhmann chápe pozorování jako „zacházení s rozlišováním“ (tamtéž: 63), čímž odkazuje k operativní logice Georga Spencera Browna. Pozorující systém zpracovává informace jako rozdíl daného a možného. Pojem smysl neoznačuje nějaký určitý, skutečný věcný obsah, ale „formu zpracování prožitku“. Zde je možné celou věc opět ilustrovat na př́lkladu:

Vidím, jak si někdo objednává pivo, a v hlavě se mi začnou rojit asociace (žizeň, nákupy, reklama...). Fenomén smyslu se objevuje ve formě nadbytku odkazů na možnosti jednání a proživání (něco je v zorném poli, něco v centru intence, něco je naznačeno marginálně, jako horizont). Odkaz se aktualizuje jako stanovisko skutečnosti, ale nezahrnuje pouze skutečné, nýbrž také možné a negativní (neskutečné, nemožné). Poslední horizont všeho smyslu nazývá Luhmann svět (tamtéž: 152). Pojem svět se má ke smyslu jako prostředí $\mathrm{k}$ systému, tj. jedná se o pojem otevřený pro všechno, co vychází vstříc smyslu.

Smysl reformuluje nutnost selekce, naznačuje určité možnosti a návaznosti a jiné činí nepravděpodobnými. Jeho funkcí je udržovat a zpř́tomňovat vysokou komplexitu pro komunikaci. Prožitky a jednání (Erleben und Handeln) jsou selekcemi podle kritérií smyslu. To ne-vybrané však může zůstat zachováno jako určitá rozmanitost světa - možná pro nějaké budoucí selekce podle poněkud změněných kritérií smyslu. 
Luhmann váže tvorbu systému na selekci možností prožitků a jednání, přičemž výsledek volby označuje jako takový, který by mohl být také jiný, než jakým je. Pro selekce neexistuje nikdy jen jedna možnost (což vysvětluje různost systémů, které se skládají z téměř identických elementů). Zde se dostáváme $\mathrm{k}$ pojmu kontingence.

Kontingence souvisí s přebytkem možností. Je filozofickým pojmem, který označuje možnost, že se něco stane nebo nestane. Všední řečí by bylo možné ríci: Není žádná jistota (řečeno negativně), nebo všechno je možné (řečeno pozitivně). V návaznosti na Immanuela Kanta je kontingence někdy ztotožňována s náhodností (Zufälligkeit). Pro Luhmanna znamená kontingence všechno, co není ani nutné, ani nemožné, co tedy je, jak to je (bylo, bude), může být, ale také je to možné jinak (Reese-Schäfer 1992: $105)$.

Zde před námi opět vyvstávají otázky, jak vzniká sociální rád, jak je vůbec tento řád možný, jak se sociální systém poprvé uvádí do chodu. Z Luhmannova pohledu jde vlastně o něco nepravděpodobného. Klade v této souvislosti otázky typu: Jak vznikají komunikace? Jak je možné, že ego rozumí-alter?

V tradični sociologii se pracuje s předpokladem, že je to umožněno společnou kulturou, společným systémem symboli̊ apod. To je pro Luhmanna neuspokojivé, protože se předpokládá něco, co má teprve být objasněno.

V souvislosti s těmito otázkami se Luhmann vrací $\mathrm{k}$ tomu, co kdysi Parsons označil výrazem dvojitá kontingence. Výchozím bodem je pro něj myšlenkový experiment: setkání dvou lidí. Setkávají se dvě černé skř́nky, které ve své komplexitě zůstávají jedna pro druhou nepri̊hledné.

Počínaje Thomasem Hobbesem značná část sociálních badatelů soudí, že faktorem, který uvádí komunikaci do chodu, je to, že dva zmínění jednotlivci v tomto aktu myslí na své vlastní zájmy. Luhmann uchopuje problém z jiného konce: Prvotní otázkou je, zda partner komunikaci prrijme, nebo odmítne (Luhmann 1993: 160).

Nemůže dojít k žádnému jednání, pokud alter dělá své jednání závislým na tom, zda jedná ego a ego své chování činí závislým na alter. Parsons tento bludný kruh řeší poukazy na hodnotový konsensus a na dlouhodobé struktury spojené se socializací a tradicí. Luhmann - podle jehož názoru nás nic neopravňuje řešit problém dvojité kontingence výlučně $v$ intencích konsenzu, který už je jakoby předem stanoven - ovšem musí hledat řešení jinde.

Jestliže Parsons vychází z tradice, Luhmannovým východiskem je „pokusné jednání“: Alter v této nejasné situaci prostě učiní nějaký pokusný krok (zde už tedy není nutné udržovat předpoklad předem sjednaného konsenzu).

Setkávají se tu dva systémy, z nichž každý vykazuje vysokou míru komplexity, dvě černé skřínky, z nichž každá určuje vlastní chování komplexními sebereferenčními operacemi. Koncentrují se na to, co mohou pozorovat v jiném systému jako input a output, mohou se to pokusit ovlivnit vlastním jednáním a $z$ toho se opět na feedbac$k u$ učí. Otázka dvojité kontingence se podle Luhmanna řš́i tak říkajíc sama sebou, za chodu. Dvojitou kontingencí vznikl nový sebereferenční kruh, který v sobě skrývá novou jednotku, kterou nelze redukovat na jeden $\mathrm{z}$ obou systémů. Takto vzniklou nejmenší jednotku označuje Luhmann výrazem komunikace, kterou chápe, jak již bylo řečeno, jinak než jen jako prenos informací. 
Podle Luhmannova názoru vede dvojitá kontingence svým tlakem $\mathrm{k}$ vytvoření sociálních systémů a v tomto smyslu působí autokatalyticky nikoli pouze jako popud, ale trvale (tamtéž: 177). Reaguje senzitivně na náhody, a tím uvádí do chodu evoluci; bez ní by sociokulturní evoluce nebyla možná. Jednou $\mathrm{z}$ dominantních Luhmannových myšlenek je tedy představa stále se nově vynořujících dvojitých kontingencí jako problémových situací. Tímto zpi̊sobem může podle Luhmanna vzniknout emergentní řád, který nazýváme sociální systém.

\section{Média a kódy}

Přes proklamovaný odklon od sociologické tradice se s ní Luhmann nerozešel úplně. Vrací se $\mathrm{k}$ tématu sociální diferenciace, které zavedl do sociologie už Herbert Spencer. Zakladatelskou generací sociologů byla sociální diferenciace spojována s evoluční predstavou, podle níž se sociální pokrok projevuje ve stále složitějších a diferencovanǰjších formách společenského života (tj. s představou, že vyspělé společnosti jsou diferencovanější než společnosti méně vyspělé). Luhmann se $\mathrm{k}$ pojmu diferenciace vrací a $\mathrm{v}$ rámci své teorie ho rozpracovává jako problém diferenciace systémové.

Diferenciací systému rozumí Luhmann evolučně probíhající proces rozčlenění společenského systému v systémy dílčí. Tím, jak roste komplexita společenského systé$\mathrm{mu}$, vzrůstá tlak na selekci, která vede $\mathrm{k}$ vyčlenění podsystémů $\mathrm{s}$ vysokou autonomií. Vytváření subsystémů probíhá autokatalyticky. Subsystémy jsou pro sebe navzájem okolními světy. Společnost se z tohoto pohledu jeví jako diferencovaná jednota, jako celek skládající se $z$ funkcionálně závislých a zároveň autonomních sociálních systémů. Moderní společnosti - na rozdíl od dř́vějších, segmentárně nebo hierarchicky členěných společností - jsou charakterizovány funkční diferenciací, tzn. množstvím subsystémů.

Tato skutečnost přináši problém sjednocení dílčích systémů a integrace jejich specifických výkonů. Jednota společenského celku nespočivá - tak jako u Parsonse $\mathrm{v}$ akceptování jednotného hodnotového či normativního systému, ale poukazuje opět $\mathrm{k}$ problematice dvojité kontingence.

S diferenciací systému vznikají dílči systémy a vzájemné vztahy mezi nimi, které ve zvýšené míře vykazují to, co Luhmann nazývá kontingence: možnost, že systémy a jejich vztahy k sobě mohou, ale nemusí být nutně tak, jak jsou.

Máme-li pochopit fungování moderní diferencované společnosti, musíme se vrátit znovu k problematice komunikace a smyslu, $\mathrm{k}$ otázce, jak lze propojovat jednotlivé autopoiesis. Společnost jako nejrozsáhlejši sociální systém se z této perspektivy jeví jako souhrn všech smysluplných, na sebe vztažených komunikací. $\mathrm{K}$ zabezpečení těchto komunikací jsou zapotřebí speciální komunikační média.

Modelem média, které umožňuje porozumění a komunikaci přes společný kontext vnímání, je jazyk. Rozšíření kapacity pro dosažení adresáta přinesla hromadná sdělovací média, jako jsou písmo, knihtisk nebo rozhlas. Ta navíc umožňují komunikaci, která už není vázána na př́tomnost. Zároveň se ovšem usnadnilo odmítnutí komunikace, a tím se zvýšila nepravděpodobnost př́jimu. 
Zde se už dostáváme $\mathrm{k}$ problematice symbolicky generalizovaných komunikačních médií: Jestliže nelze někoho přemluvit, je nutno hledat jiné formy, které budou motivovat přijetí návrhu komunikace. To se může dít nabídnutím peněz, hrozbou násilné moci, apelem na společné hodnoty a představy, poukazem na evidenci pravdy atp. Tato komunikační média spojují selekci s motivací prostřednictvím symbolické generalizace.

Jeden $\mathrm{z}$ hlavních znaků společenské evoluce vidíme $\mathrm{v}$ diferencování jednotlivých komunikačních oblastí, jakými jsou hospodářství, právo, politika, věda, náboženství, výchova, umění, intimní vztahy, a ve specializaci rozdílných médií a kódů.

\begin{tabular}{lll} 
Systém & Médium & Kód \\
\hline hospodářství & peníze & platba/neplacení \\
právo & zákony & právo/bezpráví \\
politika & moc & mít/nemít \\
věda & vědecké poznatky & pravda/nepravda \\
náboženství & víra & imanence/transcendence
\end{tabular}

(Upraveno dle Reese-Schäfer 1992: 131)

Pojem symbolicky generalizovaných komunikačních médií se nevztahuje na běžně chápané prostředky hromadné komunikace, nýbrž se jedná o taková média, jako jsou peníze, zákony, moc, víra, vědění a láska. Vưdčí diference, které působí při vytváření funkčně specifických subsystémů, Luhmann označuje jako binární kódy. Symbolická generalizace představuje spolu s binární schematizací dvě strukturální vymoženosti, které působí jako autokatalyzátory; vznikají v komunikačních systémech a v selektivních procesech těchto systémů zesilují šanci komunikačního úspěchu.

Dílčí systémy, jako jsou hospodářství, právo, věda, politika či vzdělávání, jsou funkcionálně diferencovány podle míry jim vlastních binárních kódů, kolem nichž se pak vytvářeji sémantiky specifické pro tyto jednotlivé subsystémy. Protože významným rysem komunikačních procesů je kontingence - tzn. možnost jednat tak, nebo ale také jinak - znamená kódování zásadně možnost duplikace všech variant ve formě ano-ne. Luhmann nepohliží na kódy ani jako na hodnoty, ani jako na řadu symbolů, nýbrž se specifickou abstrakcí jako na disjunkce: ano-ne, mít-nemít, pravda-nepravda, právo-bezpráví, krása-ošklivost apod.

Autonomie jednotlivých subsystémů spočívá v použivání odpovídající diference. Např. diferenciace ekonomiky jako autonomního společenského subsystému začíná etablováním symbolicky generalizovaného komunikačního média - vývojem peněz (Luhmann 1989: 230). Elementy ekonomiky jsou platby, binárním kódem ekonomického systému je platba-neplacení, jazyk představují ceny, které podmiňují a programují platby.

$\mathrm{V}$ určitých případech mohou různé systémy použivat totéž diferenciační schéma, např.: norma-odchylka, úspěch-neúspěch, uznání-opovržení.

Kód sám nemůže být kritériem selekce. Kritéria pro správnost přiřazení hodnot kódu označuje Luhmann jako programy. Autonomie jednotlivých subsystémů spočívá $\mathrm{v}$ tom, že každý z nich má své vlastní programy. 
Tato funkční specifičnost ovšem zesiluje vzájemnou závislost. Jednotlivé subsystémy jsou v silné múře odkázány na funkce jiných subsystémů. Autonomie a závislost jsou ve vzájemně potencovaném, stupňovaném poměru. Ačkoli jsou sociální systémy sebereferenční, neznamená to, že pro ně prostředí představuje bezvýznamnou, zbytkovou kategorii, naopak systém může vyvíjet svou identitu pouze v diferenciaci k prostředí, a tím se stává jeho poměr $\mathrm{k}$ prostředí konstitutivním faktorem jeho vlastní sebetvorby.

Prostředí je mnohem komplexnější než sám systém (prèdstavuje množství systémů, např. biologických a psychických). Systém zachycuje toto své prostředí diferencovaně (např. když používám počítač, nemusím vědět, jak byl zkonstruován), registruje každý druh prostředí jen v míře svého vlastního diferenciačního schématu.

Vztah mezi systémem a prostředím vyjadřuje Luhmann pojmem rezonance. Schopnost rezonance jednotlivých systémů je ohraničená (Morel 1995: 208). To, co dnes nap̌r. označujeme jako ekologické ohrožení a rizika, je systémovou teorii nahlíženo právě jako problém této rezonance, jako otázka nízké rezonanční schopnosti mezi dílčími systémy společnosti a mezi chováním společenského systému a jeho prostředím. Je to otázka nedostatečné schopnosti komunikovat a zpracovávat informace. Luhmann ukazuje, že $\mathrm{v}$ žádném př́padě nelze považovat za samozřejmé a spoléhat na to, že stavy a změny životního prostředí naleznou ve společnosti rezonanci. Naopak, sociokulturní evoluce byla zjevně založena na faktu, že společnost jako relativně uzavřený systém na své prostředí príliš nereagovala.

Zdá se, že rrízení společnosti je vzhledem $\mathrm{k}$ množství médií a kódů stále problematičtější a stále méně efektivní. Např. v hospodářském systému je zpracování informací vázáno v první řadě na ceny, tímto jazykem je vše „filtrováno“, na poruchy, které nelze v daném jazyce vyjádřit, nemůže ekonomika reagovat (Luhmann 1986: 122). Jak potom ovšem může vzniknout rezonance pro problémy životního prostředí ve společnosti, která reaguje na všechny druhy problémů jen ve formě svých specializovaných systémů, médií a kódů a v níž se staré, multifunkční instituce rozvolnily nebo ztratily svůj význam? Nastolením těchto a podobných otázek Luhmann dokazuje, že jeho teorie sociálních systémů není jen samoúčelnou intelektuální hrou, nýbrž velmi významným nástrojem zachycení a objasnění problémů moderní společnosti.

\section{Literatura}

BÜHL W. L.: Grenzen der Autopoiesis. In: Kölner Zeitschrift für Soziologie und Sozialpsychologie, Jg.39, 1987, s. 225-254.

KISS G.: Grundzüge und Entwicklung der Luhmannschen Systemtheorie. Fernand Enke Verlag, Stuttgart 1986

MOREL J. u. a.: Soziologische Theorie: Abriß der Ansätze ihrer Hauptvertreter. Oldenbourg, München-Wien 1995

MUCHA I.: Některá východiska Luhmannovy kritiky současné sociologické teorie. In: Soudobá teoretická sociologie na západě: Příspěvky ke kritické analýze. Kolektiv autorů. Ústav pro filozofii a sociologii ČSAV, Praha 1989

LUHMANN N.: Liebe als Passion: Zur Codierung von Intimität. Suhrkamp, Frankfurt am Main 1982 
LUHMANN N.: Ökologische Kommunikation. Westdeutscher Verlag, Opladen 1986

LUHMANN N.: Soziale Systeme: Grundriß einer allgemeinen Theorie.(4. Auflage) Suhrkamp, Frankfurt am Main 1993

LUHMANN N.: Soziologische Aufklärung. Bd. 1, Aufsätze zur Theorie sozialer Systeme. (6. Auflage) Westdeutscher Verlag, Köln und Opladen 1991 (a)

LUHMANN N.: Soziologische Aufklärung. Bd. 2 Aufsätze zur Theorie der Gesellschaft. (4. Auflage) Westdeutscher Verlag, Köln und Opladen 1991 (b)

LUHMANN N.: Die Wirtschaft der Gesellschaft. (2. Auflage) Suhrkamp, Frankfurt am Main 1989

LUHMANN N.: Die Wissenschaft der Gesellschaft. Suhrkamp, Frankfurt am Main 1990

PARSONS T.: Zur Theorie sozialer Systeme. Herausgegeben von Jensen S., Westeutscher Verlag, Opladen 1976

PŘIBÁN J.: Sociologie práva. Sociologické nakladatelství, Praha 1996

REESE-SCHÄFER W.: Luhmann zur Einführung. Junius, Hamburg 1992

TREIBEL A.: Einführung in soziologische Theorien der Gegenwart. Leske + Budrich, Opladen 1993

WILLKE H.: Systemtheorie (3. Auflage). Gustav Fischer Verlag, Stuttgart 1991

\section{Luhmann's Theoretical Attempt at Identifying the Complexity of Modern Society}

\section{Sum mary}

The German sociologist Niklas Luhmann ranks among the scholars who have tried to give sociology a new direction and orientation. His theory represented an attempt to describe the world by distinguishing between system and environment. A key place in Luhmann's thought on social systems is occupied by the terms "complexity", "contingency" and "autopoiesis." Growing complexity and functional differentiation are the main marks of modern society. For Luhmann the basic units of social systems are not individuals, but communications. In this context he is returning to Parsons' idea of double contingency. The internal differentiation of a system involves the emergence of subsystems within it, and mutual relations between such subsystems, which exhibit greater degrees of just that characteristic which Luhmann defines as contingence. One of the main signs of social evolution lies in the differentiation of individual communicational fields - such as the economy, law, politics, science, religion, education, art, intimate relations - and in the specialization of different media and codes. The great number of these media and codes means that today the operation of society is ever more complicated and problematic. 